Research Article

\title{
Investigation of Antibacterial Susceptibility of Ag-Doped Oxide Coatings onto AZ91 Magnesium Alloy by Microarc Oxidation Method
}

\author{
Ebru Emine Sukuroglu \\ Department of Mechanical Engineering, Gümüşhane University, 29100 Gümüşhane, Turkey \\ Correspondence should be addressed to Ebru Emine Sukuroglu; eesukuroglu@gumushane.edu.tr
}

Received 25 August 2017; Revised 24 November 2017; Accepted 13 December 2017; Published 18 February 2018

Academic Editor: Claudio Pettinari

Copyright (c) 2018 Ebru Emine Sukuroglu. This is an open access article distributed under the Creative Commons Attribution License, which permits unrestricted use, distribution, and reproduction in any medium, provided the original work is properly cited.

\begin{abstract}
This study is focused on enhancing surface characteristics of AZ91 alloy with the microarc oxidation (MAO) method and bringing in antibacterial susceptibility to it. It is aimed to bring in antibacterial effect of silver (Ag) to AZ91 magnesium base materials covered with the MAO method. The structural and chemical compositions of the coating were analysed by using XRD, SEM, and EDS. In order to analyse antibacterial susceptibilities and bacteria adhesions, bacteria are marked using crystal violet in antibacterial efficacy tests. Susceptibility of coatings to Staphylococcus aureus (S. aureus-ATCC 29213) bacteria having high adhesion is analysed. In the study, it is concluded that the silver-containing coatings have a lot poor bacterial susceptibility than silver-free coatings, and noncoated samples have very strong bacterial susceptibilities. When the antimicrobial activity of the samples coated on silver-containing electrolyte is evaluated (zone diameter $\sim 40 \mathrm{~mm}$ ), it is found as sensitive. Antimicrobial activity of samples coated in silver-free electrolyte is found as medium-sensitive (zone diameter $\sim 15 \mathrm{~mm}$ ), and uncoated samples are observed to form any zones against bacterial infection.
\end{abstract}

\section{Introduction}

Bones constituting human body can confront with disfunction due to various traumatic cases, accidents, aging, and/or various diseases. However, the most important feature of the bones is being self-healing. Bones need time to heal themselves when they experience full or partial function loss in consequence of various cases. Bones are required to benefit from biomaterials until they heal themselves to function properly. Natural and artificial materials used on behalf of supporting or undertaking the function are called as biomaterials [1].

Magnesium, as one of our rare options of biodegradable metals, owing to its almost nonexistent toxicity in human body, osteointegrative, and osteoproliferative effects has already entered medical use, for example, as degradable vascular stent and implant materials used in orthopedics and dental surgery [2]. However, the most significant negation with which biomaterials can confront in the human body is biomaterial-related infection. This situation can negatively affect the surface of biomaterial. Due to this reason bringing antibacterial feature to the surface of biomaterials will prevent bacterial adhesion and reduce infection risk. Another negation with which biomaterials can confront in the human body is noncoalescence of bone and biomaterials. There are many studies to provide creation of connective tissue between biomaterial inserted in human body and bone [1-4]. However, applying surface treatment onto biomaterials, making coatings, and various mechanic/chemical processes are among the most preferred methods in recent years. In order to make the oxide layer particularly bioactive and to provide the desired properties, many different methods are applied today. These are anodization, ion spattering, chemical etching, sol-gel, electrolytic deposition, plasma spraying, and microarc oxidation $[3,4]$. The microarc method is based on the principle of microarc formation in the basic solution due to the high voltage on the surface of the anode material. The oxide coatings obtained by 
the MAO method are rough, with a strong bond to the porous and substrate layer. At the same time, various ions added into the electrolytic solution can penetrate into the coating [4-7]. The ions found in the electrolytic solution, such as calcium, phosphorus, and silver, have been discovered in a variety of researches that give the oxide layer bioactive properties. The oxide layer formed by these ions improves the bone tissue conformity of the implant material. Many studies have attempted to deposit metals with antibacterial properties such as silver, copper, and zinc on the coating. Among them, silver is one of the most important antibacterial metals known for centuries. Recent research has revealed that silver ions react with surface proteins of bacteria and inactivate them. In addition, silver ions entering the bacterial cell interfere with thiol groups of proteins stop DNA fragmentation $[8,9]$.

In this study, a porous oxide layer, having high bioactivity, is bred on biomaterial AZ91 magnesium base materials with the microarc oxidation (MAO) method. Furthermore, it is known that silver and their compounds have antibacterial properties, so that a doped oxide layer is obtained by adding silver to the electrolyte in order to impart an antibacterial property to the biomolecule surface. The antibacterial behavior of the enlarged coatings was investigated in in vitro conditions.

\section{Materials and Methods}

In this study, AZ91 magnesium alloy $(10 \mathrm{~mm}$ in diameter and $2 \mathrm{~mm}$ in thickness) whose chemical compounds are given in Table 1 was used as a base material. Before the MAO process, base materials are polished to $\mathrm{Ra} \approx 0.1 \mu \mathrm{m}$ roughness level with different grain-sized $\mathrm{SiC}$ sandpapers, and then samples are cleaned with acetone, ethanol, and pure water. When the cross-sectional image was taken to determine the coating thickness, the coated specimens were stored in liquid nitrogen and fractured brittle.

The MAO process of AZ91 magnesium alloys are carried out in the plating system produced by Faraday Electronic Ltd. The MAO process of some base materials is carried out in $\mathrm{KOH}(1 \mathrm{gr} / \mathrm{lt}), \mathrm{Na}_{2} \mathrm{HPO}_{4}(3 \mathrm{gr} / \mathrm{lt})$, and $\mathrm{Na}_{2} \mathrm{SiO}_{3}(4 \mathrm{gr} / \mathrm{lt})$ aqueous solution used as electrolyte; others' are carried out by adding silver (Ag) ( $\left.0.25 \mathrm{gr} / \mathrm{lt} \mathrm{AgNO}_{3}\right)$ to that solution. In the MAO operation, DC power supply is used in the unipolar mode at a constant voltage of $550 \mathrm{~V}$ for 15 minutes of operation at $175 \mathrm{~Hz}$ operating frequency, respectively. Sample anodes and stainless steel bath walls are used as cathodes in all experiments. The electrolyte prepared during the process is stirred and cooled with water passing through the bath walls to prevent the temperature from exceeding $30^{\circ} \mathrm{C}$. After the MAO process, the coated samples are dried by washing with pure water.

The base materials are subjected to in vitro antibacterial activity (in vitro bacterial adhesion) tests after they are coated in silver-missing electrolyte (A) and the silver-added electrolyte (B). In addition, coated surfaces and uncoated surfaces are also subjected to the same tests for comparison. Staphylococcus aureus (ATCC 29213), having a human pathogen feature, is used as a test microorganism in the
TABle 1: Chemical compounds (wt. \%)

\begin{tabular}{cccccccc}
\hline $\mathrm{Mg}$ & $\mathrm{Al}$ & $\mathrm{Zn}$ & $\mathrm{Mn}$ & $\mathrm{Fe}$ & $\mathrm{Si}$ & $\mathrm{Ni}$ & $\mathrm{Cu}$ \\
\hline Bal. & 9.1 & 0.85 & 0.27 & 0.02 & 0.05 & 0.001 & 0.004 \\
\hline
\end{tabular}

study. $0.1 \mathrm{ml}$ test microorganism is incubated on nutrient broth liquid medium (Merck 1.05450). Then, coated and uncoated samples are placed into liquid culture. Materials are kept in constant contact with the microorganisms by shaking at $100 \mathrm{rpm}$ at body temperature $37^{\circ} \mathrm{C}$. Microorganisms are marked using $1 \%$ crystal violet in order to examine in vitro bacterial adhesion; and 6 hours later, the microorganisms' adherence on surfaces coated in A and B electrolyte is analysed on uncoated surfaces with the Zeiss brand polarized microscope. Besides, coated and uncoated samples are transacted based on the disk diffusing method in order to test their susceptibility. Fresh cultures of bacterial strains grown in the NA medium for 24 hours are planted into $100 \mathrm{ml}$ nutrient broth (NB) medium prepared in $250 \mathrm{ml}$ Erlenmeyer flask and incubated for $24 \mathrm{~h}$ at $28^{\circ} \mathrm{C}$. The absorbance of the growing cultures is adjusted to 108 cells $/ \mathrm{ml}$, and they are seeded on the whole surface of NA mediums with the help of sterile swaps. Petri dishes are left to dry at room temperature for $2 \mathrm{~h}$. Tested coated samples are placed in the middle of the Petri dishes, each containing different bacteria. These Petri dishes are left to incubate at $28^{\circ} \mathrm{C}$ for 24 hours; and then, the diameter of inhibition zone around the disc is evaluated as the zone where the growth of cultures is inhibited. Inhibition zone $(\mathrm{mm})$ is measured, and the acquired value is used to determine the susceptibility of the bacterial strain to the coated materials. An empty disk is used as controller, and the disc's diameter is added to zone measurements. The tests are conducted 3 times with 3 repetitions each time under the same conditions.

\section{Results and Discussion}

Figures 1 and 2 show the surface morphologies and crosssectional images of the coatings obtained on the base materials after the MAO process. When these images are examined, it is observed that coatings grown on the base material have a rough surface, volcano-like formations caused by many different sized microerosions and a large number of circular micropores at the ends of some large formations. These formations occur due to microdischarge resulted from the nature of the MAO process. The regional melting that occurs during the coating process and subsequently solidification trace that occurs by following a circular path cause pores in the coating to have circular forms [8-10].

Figures 1(a) and 1(b) show coatings grown in A electrolyte and B electrolyte, respectively. When the shapes are carefully examined, it is seen that the surface of coating grown in silver-added electrolyte is more uniform. It is believed that different distribution in uniform and nonuniform structures of the pores are resulted from local melts occurring in arc channels and distribution of melted material [11, 12]. A very thin and uniform structure on the surface of base material is due to the numerous 


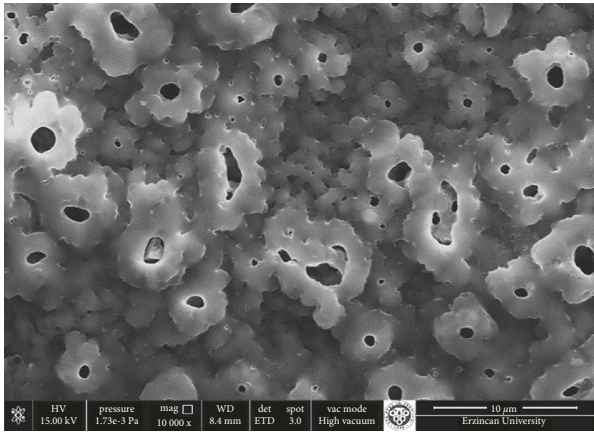

(a)

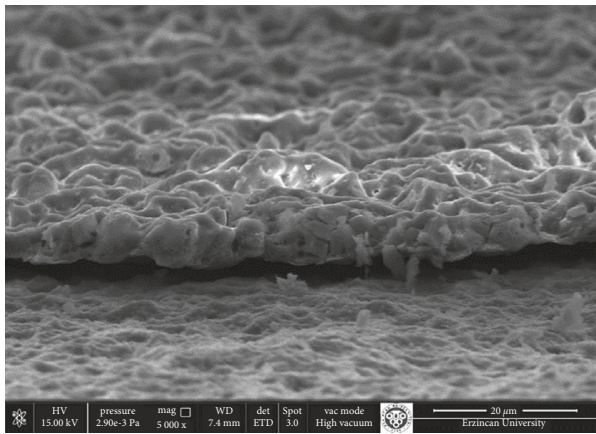

(c)

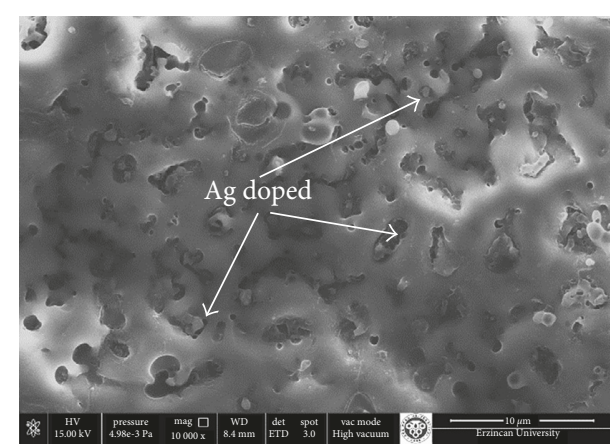

(b)

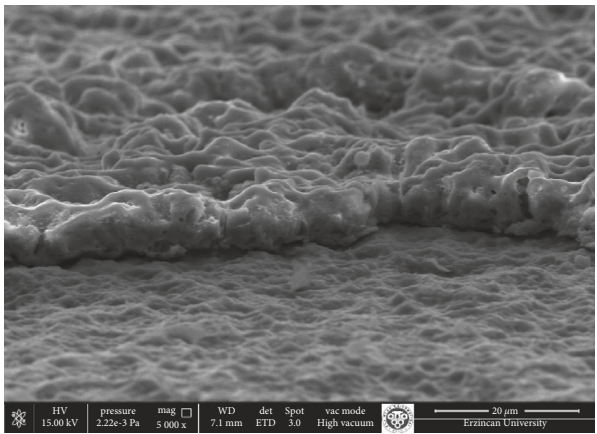

(d)

FIGURE 1: SEM images after MAO. Surface images of samples coated in (a) electrolyte A and (b) electrolyte B. Cross-sectional images of samples coated in (c) electrolyte A and (d) electrolyte B.

microdivisions occurring at the beginning of the microarc process. As the processing period continues, the number of microdivisions gradually reduces and individual microdivorces begin, and nonuniform larger pores are obtained. When the studies in the literature are examined, the effect of coating parameters on the structure of surface pores is seen clearly $[9,13-16]$.

Figure 1(c) shows the cross-sectional views of grown coatings. There is no difference in the thicknesses of samples $(\sim 7 \mu \mathrm{m})$ coated in A and B electrolytes. It is believed that this is due to the fact that $\mathrm{Ag}$ ions are placed among micropores. It is noted that these pores in Figure 1(b) are more full and homogeneous than Figure 1(a). This is the explanation that the pores are filled during the coating. For both coated samples, EDS analysis was performed from both the inner parts and the outer parts of the pores. But only in the Agdoped coating, Ag was found on the inside of pores. The adaptation between coating and surface is shown in Figure 1(c). The coating grows quite adherent to the surface, and there is no break or split.

In the microarc oxidation of magnesium and its alloys, porous and rough magnesium oxide layer formed on the surface, and it is binded firmly to the implant surface due to the structure similar to bone tissue. It is possible to form a strict binding between tissue and bone in a shorter period with the formation of high porous, rough layer and hydroxyapatite. Due to the improvement in adaptation of bone tissue, healing time becomes shorter after implantation. On the other hand, increase of roughness and porosity creates an environment that is suitable for bacteria growth. In order to prevent infections after implantation, an antibacterial surface should be formed on the implant. Antibacterial properties of silver is known for ages. The silver, which penetrates to the oxide layer, provides acquirement of antibacterial properties of coating and reduces complications after implantation [9].

Figure 2 shows XRD patterns of coatings grown by the MAO process. In the literature, it is stated in detail that $\mathrm{MgO}$, grown by the MAO process, grows in $\mathrm{MgO}$ and $\mathrm{Mg}_{3}\left(\mathrm{PO}_{4}\right)$ crystal structures. $\mathrm{MgO}$ phase from these crystal structures is thermodynamically the more stable structure than $\mathrm{Mg}_{3}\left(\mathrm{PO}_{4}\right)$. The $\mathrm{MAO}$-grown coatings consist of $\mathrm{Mg}_{3}\left(\mathrm{PO}_{4}\right)$, which is a semistable phase at low temperatures, and $\mathrm{MgO}$ phase, which is a stable phase at high temperatures [17-19]. Also, in addition to current phases, different phases can be obtained depending on the chemical composition of the solution used in the coating process. However, it is quite difficult to determine these phases by XRD. When XRD patterns of grown coatings in Figure 2 are examined, $\mathrm{MgO}$ and $\mathrm{Mg}_{3}\left(\mathrm{PO}_{4}\right)$ characterizing are seen. At $2 \theta=27^{\circ}, 28^{\circ}, 47^{\circ}$, $58^{\circ}, 66^{\circ}$, and $78^{\circ}$, the $\mathrm{MgO}$ phases are observed to be at high density comparably to the literature. During the MAO operation, the effect of the high voltage value leads to very high values of the pressure and temperature (102 MPa and $2.104 \mathrm{~K})[14]$ in the discharge channels, and consequently enables formation of stable $\mathrm{MgO}$ phase. High pressure and temperature help to form the $\mathrm{MgO}$ phase easily. Low thermal conductivity of oxide coating acts as a thermal barrier and causes coating to become hot. This facilitates the formation of the $\mathrm{MgO}$ phase. However, $\mathrm{Ag}$ peaks are not 


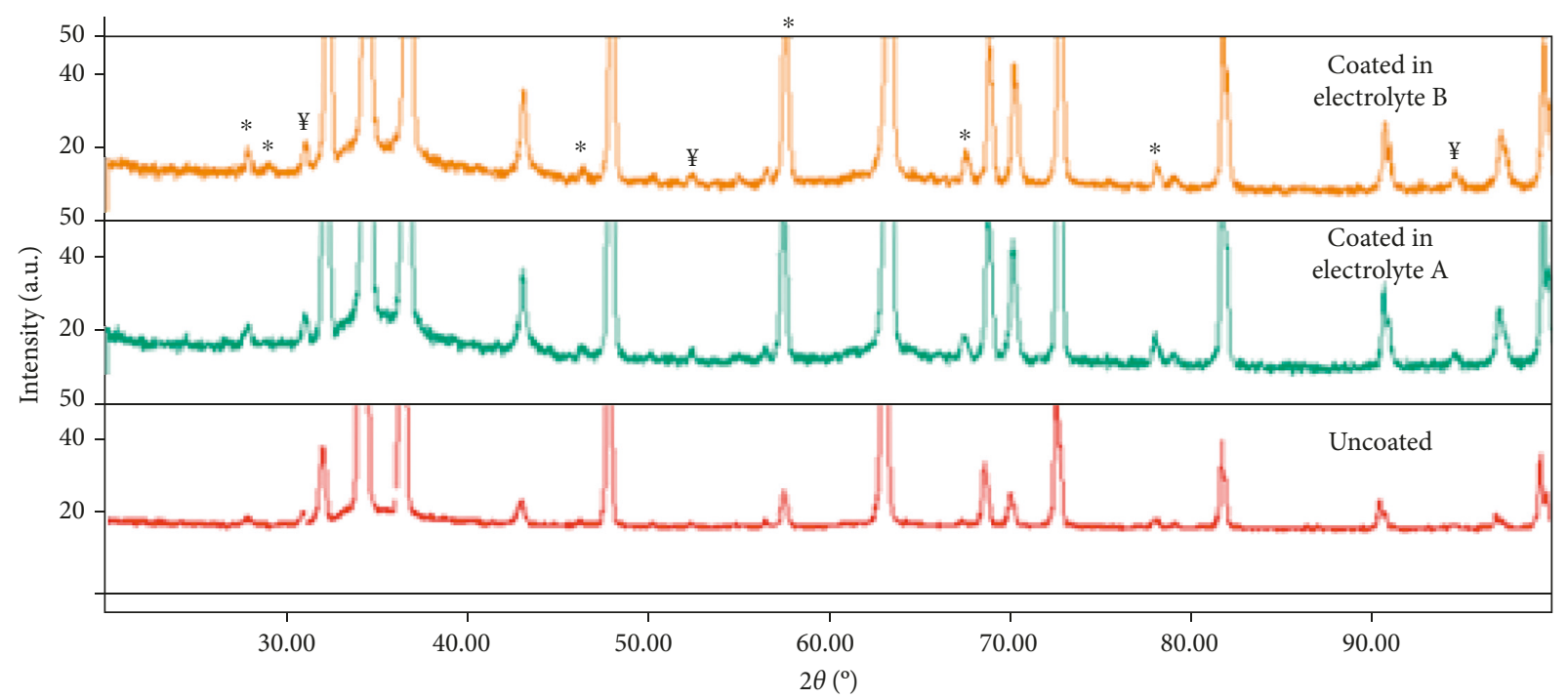

(a)

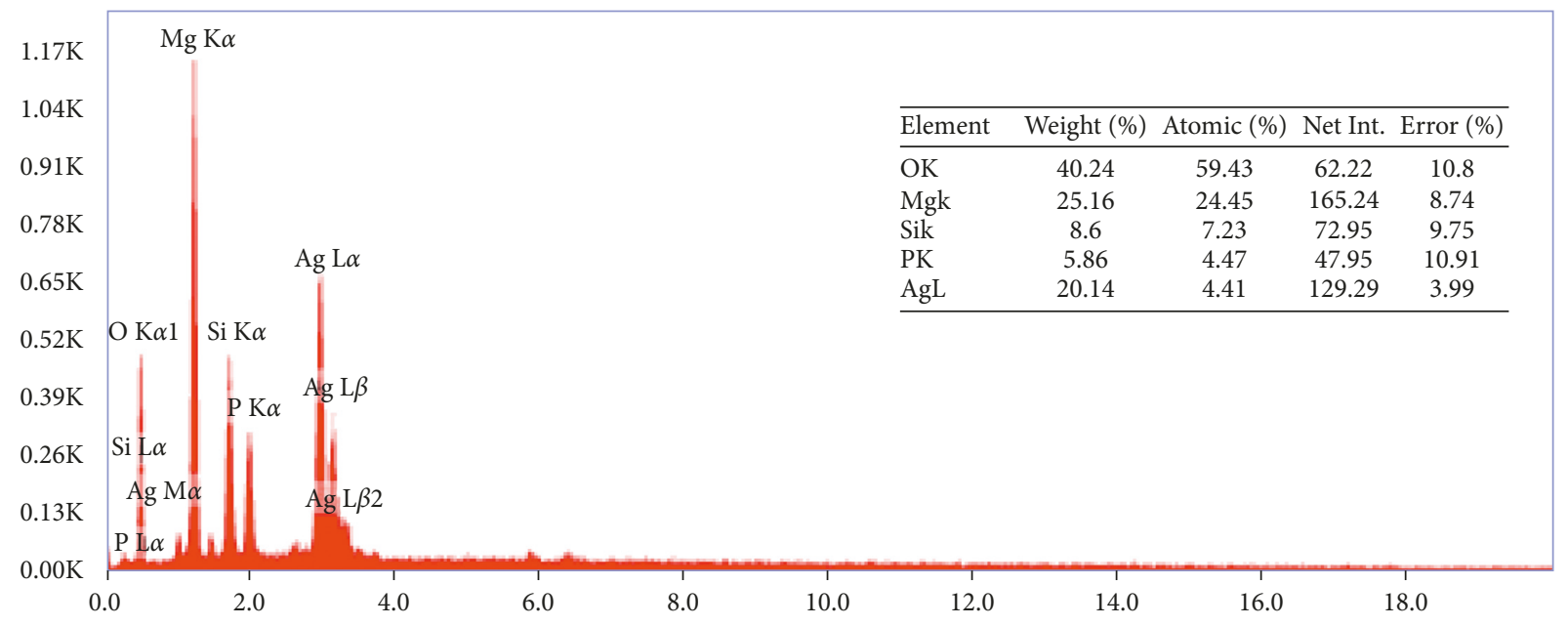

Lsec: 49.00 Cnts $0.000 \mathrm{keV}$ Det: Octane Plus Det

(b)

FIgURE 2: (a) XRD patterns and (b) EDS patterns of the coated and uncoated Mg samples. $*=\operatorname{MgO} ; ¥=\mathrm{Mg}_{3}\left(\mathrm{PO}_{4}\right)$.

seen in XRD analyses. This is believed to be due to the fact that the Ag ions are located into the micropores on the surface. Figure 2(b) shows the EDS analysis from micropores in the surface. The Ag peaks found in the EDS analyses indicate that the $\mathrm{Ag}$ ions are placed in the micropores.

It is identified by $1 \%$ crystal violet marking of S. aureus, which is selected to use for the evaluation of microbiological adhesion in in vitro tests and is shown in Figure 3. Prepared samples are displayed 6 hours later, and selected bacteria are identified in [20]. According to studies, the marked bacteria were easily detected from the surface. Figure 3(a) shows the examples which are not subjected to the coating process. When Figure 3(a) is carefully examined, it stands out that marked bacteria appear purple, and in some places, black colors appear due to multiple colonies of bacteria. S. aureus typically forms colonies that are $1.0-1.5 \mathrm{~mm}$ in diameter, black, shiny, convex with a narrow white entire margin and surrounded by clear zones extending $2-5 \mathrm{~mm}$ into the opaque medium [20]. Figure 3(b) shows the bacterial adhesion of the samples coated in electrolyte A. Some bacteria are seen on the samples coated in electrolyte A; however, when compared to uncoated samples, very few bacteria are attached to the surface. When Figure 3(b) is closely examined, it is clear that bacteria are located in micropores, and there is not any bacteria or colonie on surfaces. Figure 3 (c) shows the bacterial adhesion of the samples coated in electrolyte B. Although all the surfaces of the samples are examined in detail, no bacteria are seen adhered to the surface. In addition, as shown in Figures 3(b) and 3(c), bacteria's low adhesion to the surface results from the features of new surfaces obtained by coatings as well as silver's germicidal property. On noncoated surfaces, these bacteria were found to be very dense, whereas on the coated surface there was much less and no bacteria were found on the Ag-doped 


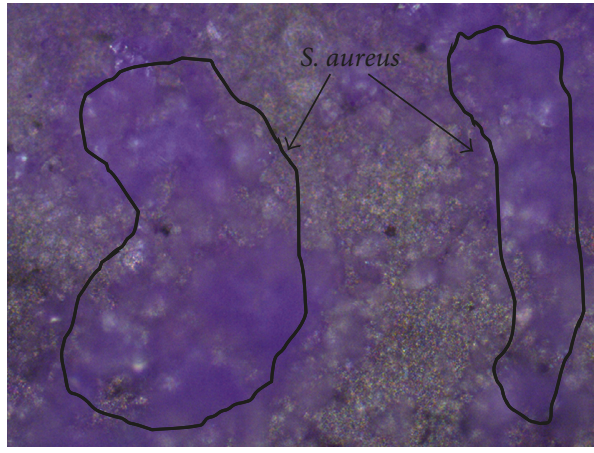

(a)

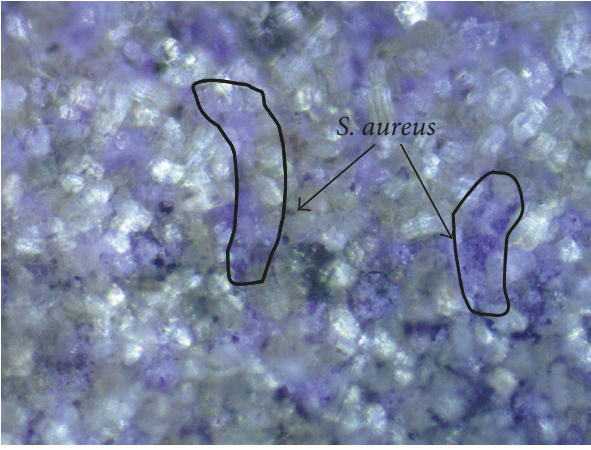

(b)

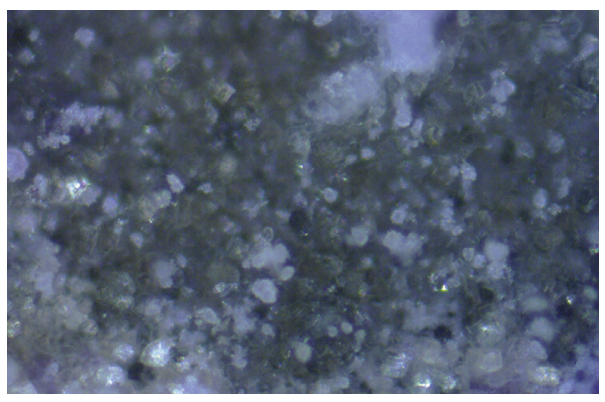

(c)

Figure 3: Microbiological adhesion in in vitro tests before and after MAO. (a) Uncoated base material, (b) samples coated in electrolyte A, and (c) samples coated in electrolyte B.

TABLe 2: The tests statistics are conducted 3 times with 3 repetitions each time under the same conditions.

\begin{tabular}{lccc}
\hline Samples & \multicolumn{3}{c}{ Resistant zones (mm) } \\
& (1) Test & (2) Test & (3) Test \\
\hline Uncoated base material & 0 & 5 & 4 \\
Samples coated in electrolyte A & 6 & 15 & 14 \\
Samples coated in electrolyte B & 16 & 18 & 16 \\
\hline
\end{tabular}

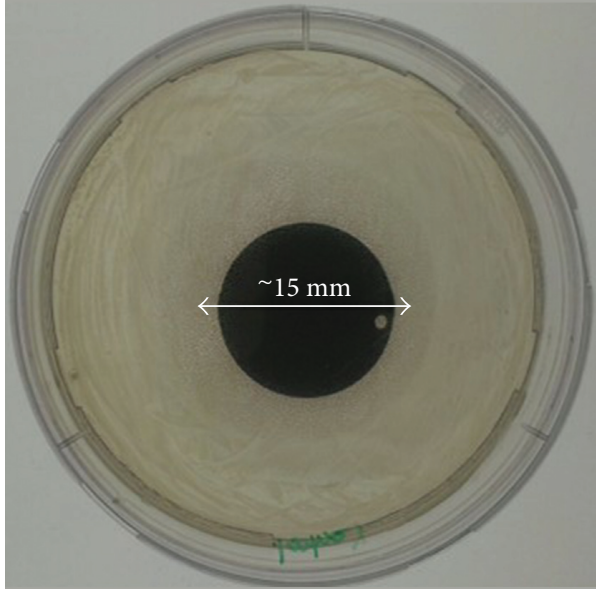

(a)

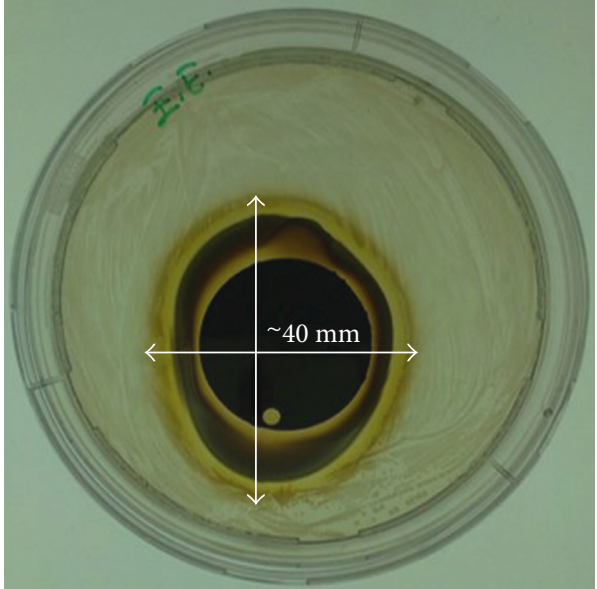

(b)

Figure 4: Inhibition zone (diameter). Samples coated in (a) electrolyte A and (b) electrolyte B. 
coating. Results from in vitro antibacterial efficacy tests are observed to yield similar results when compared to studies on silver-plated surfaces in the literature [21,22].

The tests are conducted 3 times with 3 repetitions each time under the same conditions. The results (statistics) are shown in Table 2 to analyse the diameters. In order to test their susceptibility to the coated and uncoated samples, inhibition zone (diameter) is grouped as resistant zone $(\mathrm{R}) \approx$ $0-5 \mathrm{~mm}$, medium-sensitive zone $(\mathrm{M}) \approx 6-15 \mathrm{~mm}$, and sensitive zone $(S) \geq 16 \mathrm{~mm}$ in the process of the disk diffusion method. Accordingly, when the antimicrobial activity of the samples coated in electrolyte B is evaluated (zone diameter $\sim 40 \mathrm{~mm}$ ), it is found to be resistant (Figure 4). Antimicrobial activity of samples coated in electrolyte A are found as medium-sensitive (zone diameter $\sim 15 \mathrm{~mm}$ ), whereas uncoated samples do not form any zone against bacteria.

The porous structure formed by the microarc oxidation method is convenient in terms of osseointegration, but it can provide basis for the formation of bacteria. For this reason, it is necessary to give antibacterial properties to oxidized surfaces. It is widely believed that biological coatings are required to be formed to prevent the first bacterial adhesion [23]. Therefore, a number of studies have been carried out for the purpose of bringing antibacterial properties to the surface by adding required amounts of silver, which is used for antibacterial purposes, to the electrolytes used in microarc oxidation for decades [24]. MAO stands out as the most effective and most suitable method for bioactive coatings. Tests show similar results to those in the literature and reveal that the MAO process can be used to form antibacterial biological coatings [25].

When silver is coated on the surface of any material, the surface area increases several million times, and they provide a very strong antibacterial effect. Silver, which has been reported to kill mutant or nonmutated 650 known pathogens in a very short time, is therefore regarded as a natural antibiotic in medical circles. The metabolism of bacteria, viruses, or fungus cells that contact silver, which is smaller than a living cell, is impaired, and electrolyte balance is destroyed and enzymes die, becoming ineffective, and they excreted through body's immune system. As silver breaks the metabolism of viruses and bacteria, they cannot develop any defence and immune system. Furthermore, in the literature, silver ions are stated not to react with or damage any cell due to cell membrane of the human body [25-28].

\section{Conclusion}

This study is focused on enhancing surface characteristics of AZ91 magnesium alloy with the MAO method and bringing antibacterial susceptibility to it, and the acquired results are summarised below:

(i) MAO method is successfully applied to AZ91 magnesium alloy for the Ag-doped MgO oxide coating.

(ii) Depending on microdischarge phenomenon resulting from the nature of the the MAO process, it has been observed that the coatings grown on the base material have a rough surface, volcano-like formations, and a large number of circular micropores at the end of some formations.

(iii) At $2 \theta=27^{\circ}, 28^{\circ}, 47^{\circ}, 58^{\circ}, 66^{\circ}$, and $78^{\circ}$, the $\mathrm{MgO}$ phases are observed to be at high density comparably to the literature.

(iv) It was concluded that the silver-containing coatings have a lot poor bacterial susceptibility than silverfree coatings, and noncoated samples have very strong bacterial susceptibilities.

(v) When the antimicrobial activity of the samples coated on electrolyte B is evaluated (zone diameter $\sim 40 \mathrm{~mm}$ ), it is found as sensitive. Antimicrobial activity of samples coated in electrolyte $A$ is found as medium-sensitive (zone diameter $\sim 15 \mathrm{~mm}$ ), and uncoated samples are observed to form any zones against bacterial infection.

\section{Conflicts of Interest}

The author declares that there are no conflicts of interest.

\section{Acknowledgments}

The author would like to thank the Faculty of Engineering, Department of Mechanical Engineering, and Central Research Laboratory Applications and Research Center (CRLAR) at Gümüşhane University.

\section{References}

[1] A. A. Zadpoor, "Mechanics of additively manufactured biomaterials," Journal of the Mechanical Behavior of Biomedical Materials, vol. 70, pp. 1-6, 2017.

[2] R. M. Pilliar, "Metals and orthopaedic implants-past successes, present limitations, future challenges," in Procceedings of the Materials \& Processes for Medical Device Conference: Medical Device Materials, S. Shrivastava, Ed., pp. 8-22, Anaheim, CA, USA, September 2003.

[3] M. Niinomi, "Titanium alloys for medical and dental applications," in Procceedings of the Materials \& Processes for Medical Device Conference: Medical Device Materials, S. Shrivastava, Ed., pp. 417-422, Anaheim, CA, USA, September 2003.

[4] T. Hanawa, "In vivo metallic biomaterials and surface modification," Materials Science and Engineering: A, vol. 267, no. 2, pp. 260-266, 1999.

[5] M. Aliofkhazraei, R. Shoja Gharabagh, M. Teimouri, M. Ahmadzadeh, G. B. Darband, and H. Hasannejad, "Ceria embedded nanocomposite coating fabricated by plasma electrolytic oxidation on titanium," Journal of Alloys and Compounds, vol. 685, pp. 376-383, 2016.

[6] M. Asgari, M. Aliofkhazraei, G. B. Darband, and A. Sabour Rouhaghdam, "Evaluation of alumina nanoparticles concentration and stirring rate on wear and corrosion behavior of nanocomposite PEO coating on AZ31 magnesium alloy," Surface and Coatings Technology, vol. 309, pp. 124-135, 2017.

[7] H. Sharifi, M. Aliofkhazraei, G. B. Darband, and A. Sabour Rouhaghdam, "Tribological properties of PEO nanocomposite coatings on titanium formed in electrolyte containing ketoconazole," Tribology International, vol. 102, pp. 463-471, 2016. 
[8] F. Muhaffel, "Mikro ark oksidasyon yöntemiyle titanyum esasli implantlarin yüzey özelliklerin gelişirilmesi," M.S. thesis, Istanbul Technical University, Istanbul, Turkey, 2010.

[9] H. Jeon, S. Yi, and S. Oh, "Preparation and antibacterial effects of $\mathrm{Ag}-\mathrm{SiO}_{2}$ thin films by sol-gel method," Biomaterials, vol. 24, no. 27, pp. 4921-4928, 2003.

[10] G. B. Darband, M. Aliofkhazraei, P. Hamghalam, and N. Valizade, "Plasma electrolytic oxidation of magnesium and its alloys: mechanism, properties and applications," Journal of Magnesium and Alloys, vol. 5, no. 1, pp. 74-132, 2017.

[11] E. V. Parfenov, A. L. Yerokhin, and A. Matthews, "Frequency response studies for the plasma electrolytic oxidation process," Surface and Coatings Technology, vol. 201, no. 21, pp. 8661-8670, 2007.

[12] E. Matykina, A. Berkani, P. Skeldon, and G. E. Thompson, "Real-time imaging of coating growth during plasma electrolytic oxidation of titanium," Electrochimica Acta, vol. 53, no. 4, pp. 1987-1994, 2007.

[13] R. L. Krishna and K. R. C. Somaraju, "The tribological performance of ultra-hard ceramic composite coatings obtained through microarc oxidation," Surface and Coatings Technology, vol. 163-164, pp. 484-490, 2003.

[14] A. L. Yerokhin, A. Leyland, and A. Matthews, "Kinetic aspects of aluminium titanate layer formation on titanium alloys by plasma electrolytic oxidation," Applied Surface Science, vol. 200, no. 1-4, pp. 172-184, 2002.

[15] A. L. Yerokhin, X. Nie, A. Leyland, A. Matthews, and S. J. Dowey, "Plasma electrolysis for surface engineering," Surface and Coatings Technology, vol. 122, no. 2-3, pp. 73-93, 1999.

[16] M. R. Bayati, F. Golestani-Fard, and A. Z. Moshfegh, "The effect of growth parameters on photo-catalytic performance of the MAO-synthesized $\mathrm{TiO}_{2}$ nano-porous layers," Materials Chemistry and Physics, vol. 120, no. 2-3, pp. 582-589, 2010.

[17] A. Bai and Z. Chen, "Effect of electrolyte additives on anticorrosionability of micro-arc oxide coatings formed on magnesium alloy AZ91D," Surface and Coatings Technology, vol. 203, no. 14, pp. 1956-1963, 2009.

[18] H. Chen, G. Lv, G. Zhang et al., "Corrosion performance of plasma electrolytic oxidized AZ31 magnesium alloy in silicate solutions with different additives," Surface and Coatings Technology, vol. 205, pp. S32-S35, 2010.

[19] E. E. Demirci, E. Arslan, K. V. Ezirmik, Ö. Baran, Y. Totik, and I. Efeoglu, "Investigation of wear, corrosion and tribocorrosion properties of AZ91 Mg alloy coated by micro arc oxidation process in the different electrolyte solutions," Thin Solid Films, vol. 528, pp. 116-122, 2013.

[20] W. F. Harrigan, Laboratory Methods in Food Microbiology, Academic Press, San Diego, CA, USA, 3rd edition, 1998.

[21] G. M. Gencer, S. Karadeniz, F. Y. Lambrecht, H. Havıtçığlu, S. Ozkal, and H. Baskın, "Plazma Daldırma Iyon Implantasyonu ve Biriktirme (PIII\&D) Prosesi Gerilimlerinin Azot Plazmasında Ortopedik Implant Malzemesi Ti6Al4V Yüzeyinde Oluşturulan Ag Kaplamalarının Morfolojilerine, Faz Oluşumlarına Ve E. Coli Adezyonuna Etkileri," Journal of the Faculty of Engineering and Architecture of Gazi University, vol. 32, no. 1, pp. 231-241, 2017.

[22] H. Cao, T. Cui, G. Jin, and X. Liu, "Cellular responses to titanium successively treated by magnesium and silver PIII\&D," Surface and Coating Technology, vol. 256, pp. 9-14, 2014.

[23] H. Cao, Y. Qiao, X. Liu et al., "Electron storage mediated dark antibacterial action of bound silver nanoparticles: smaller is not always better," Acta Biomaterialia, vol. 9, no. 2, pp. 5100-5110, 2013.
[24] P. Zhang, Z. Zhang, W. Li, and M. Zhu, "Effect of Ti-OH groups on microstructure and bioactivity of $\mathrm{TiO}_{2}$ coating prepared by micro-arc oxidation," Applied Surface Science, vol. 268, pp. 381-386, 2013.

[25] M. Rai, A. Yadav, and A. Gade, "Silver nanoparticles as a new generation of antimicrobials," Biotechnology Advances, vol. 27, no. 1, pp. 76-83, 2009.

[26] F. Karabudak, R. Yesildal, E. E. Sukuroglu et al., “An investigation of corrosion resistance and antibacterial sensitivity properties of nano-Ag-doped $\mathrm{TiO}_{2}$ coating and $\mathrm{TiO}_{2}$ coating grown on NiTi alloy with the micro arc oxidation process," Arabian Journal for Science and Engineering, vol. 42, no. 6, pp. 2329-2339, 2017.

[27] X. Chen and H. J. Schluesener, "Nanosilver: a nanoproduct in medical application," Toxicology Letters, vol. 176, no. 1, pp. 1-12, 2008.

[28] T. D. Aydogan, F. Muhaffel, M. M. Kilic et al., "Optimisation of micro-arc oxidation electrolyte for fabrication of antibacterial coating on titanium," Materials Technology, pp. 1-8, 2017. 


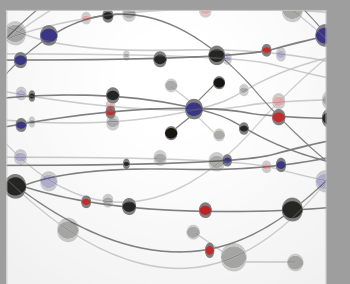

The Scientific World Journal
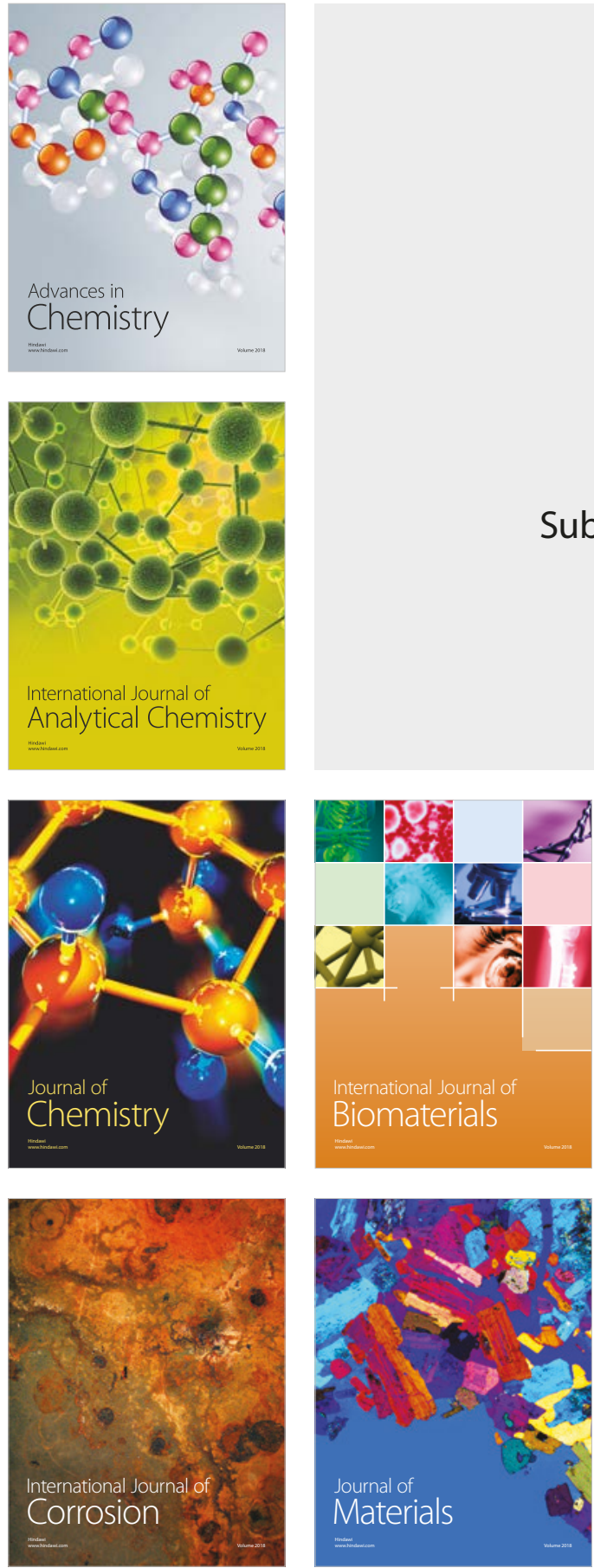

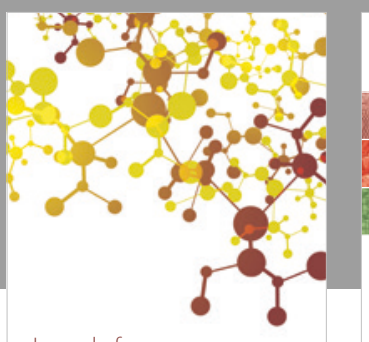

Journal of

Applied Chemistry
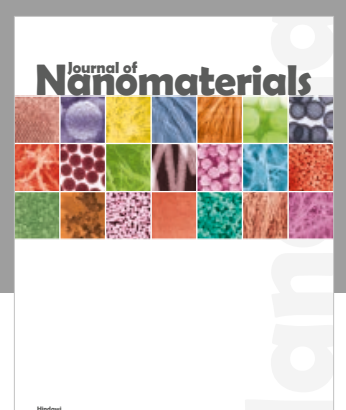

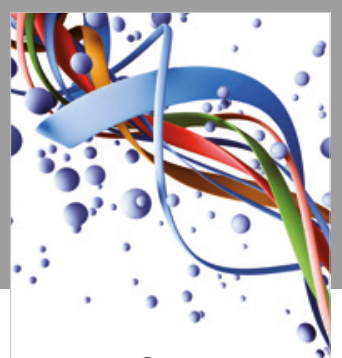

Scientifica

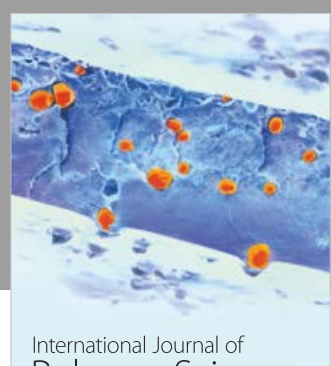

Polymer Science

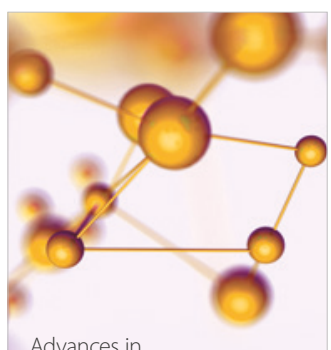

Physical Chemistry
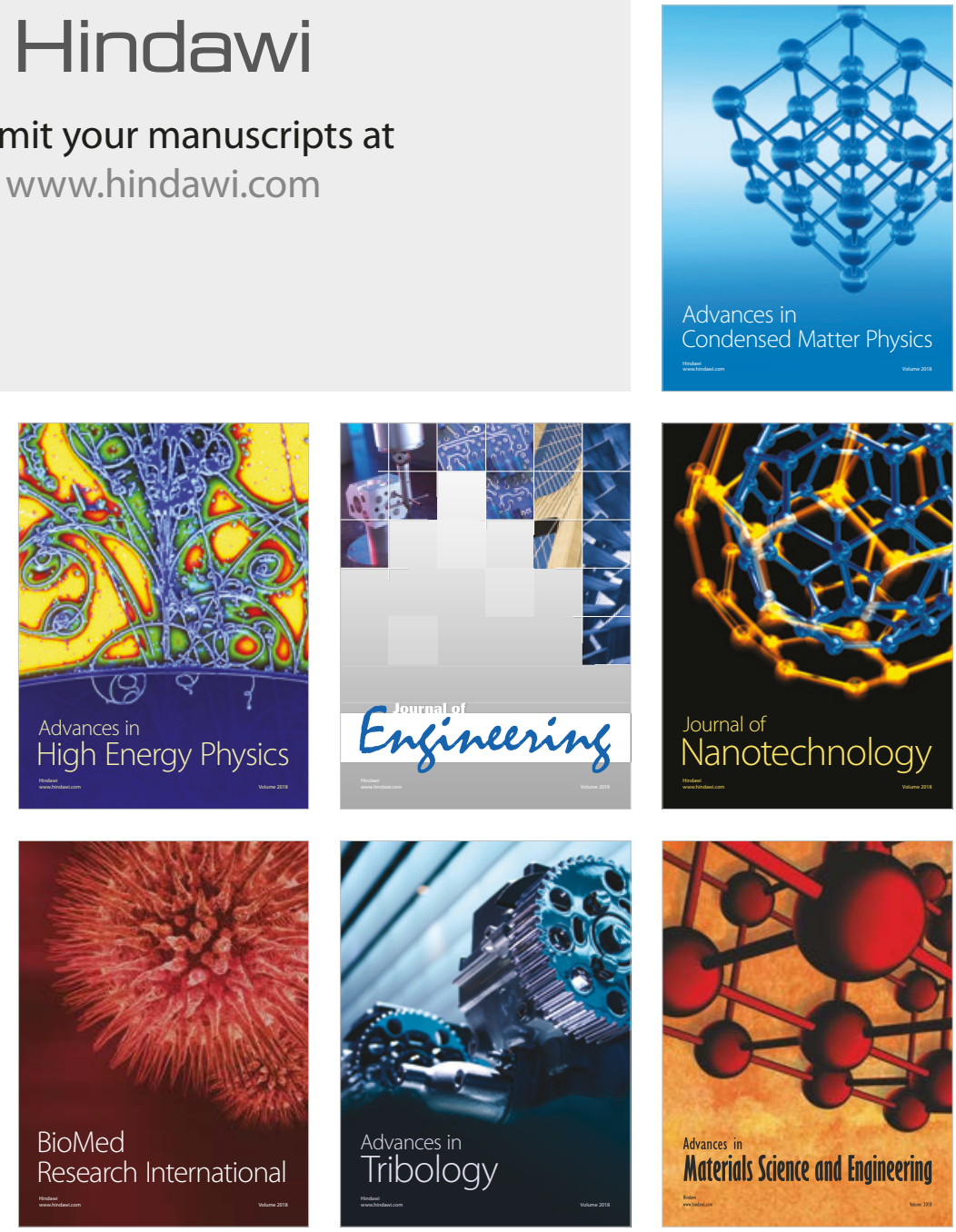